\title{
'BUT YOU, WHO DO YOU SAY I AM?' \\ A HOMILY ON IDEOLOGICAL FAITH FROM THE GOSPEL OF MARK ${ }^{1}$
}

\author{
Piet Naudé \\ Nelson Mandela Metropolitan University \\ Port Elizabeth
}

\begin{abstract}
This article attempts to reconstruct the nature and effect of an ideological faith through a careful analysis of the Markan narrative. Originally a sermon, the article argues that the question of Jesus' identity is the leading question in the gospel. The misunderstanding of those closest to Him - the disciples - provides interesting clues into self-interested faith. The article ends with the question of how the resurrected Christ can indeed deconstruct ideology and commission the disciples anew. In the footnotes, a commentary on the South African situation is provided.
\end{abstract}

Keywords: Narrative Analysis, Gospel Of Mark, Ideological Faith, Homiletics

\section{Seeking the Grounds of an Ideological Faith}

One perennial question faced those of us who were born under apartheid and later studied theology during the time that South Africa struggled to liberate herself from her past: How was it possible to not only give Christian legitimacy to an inhuman, racist system, but actually co-design such a system with a direct and pious appeal to God and the Scriptures?

Many books and articles were written to analyze the ideologizing of the gospel by white Reformed churches. It slowly emerged that what was at stake was a deadly combination of nationalistic power and an enabling religious hermeneutics, resulting in an Afrikaner civil religion. $^{2}$ The rise of Afrikaners after the defeat in the Anglo-Boer War (1899-1902) and formation of the Union of South Africa (1910) was the engine that fuelled a fervent nationalism that upheld itself with strong "in-group" (Afrikaners) and "out-group" (English, blacks and communists) boundaries. Coupled to this was the appropriation of Scripture by some that identified Afrikaners as God's people, ${ }^{3}$ with a mission in Africa, based on a differentiated pluralism assuming that God, from creation, assigned to each people (Volk) his own land and development potential.

It is possible - and has been done - to show the complex pro- and counter theological currents in the years between 1935 and 1990. The roots of an apartheid theology lie in an

\footnotetext{
A shortened version of a contribution to the English Festschrift in honor of Michael Welker's $60^{\text {th }}$ birthday to be published in 2007/8.

2 "There can be hardly any doubt that religion and nationalism were the main ideological forces that impacted on the Afrikaners during the twentieth century. The two were interrelated." The exact relationship between the two is a matter of debate, however. See for a discussion, Giliomee 2003:221-226, a foremost South African historian who recently published a major, and widely acclaimed work, The Afrikaners (2003).

3 With reference to O'Brien's distinction between a "holy nationalism" and limited self-understanding as a "holy people", Giliomee gives strong evidence that, unlike Germany under National-Socialism, Afrikaners never claimed an exclusive right to God's favor, though there was a strong sense of God's providential hand in their history (Giliomee 2003:224).
} 
interesting combination of neo-Calvinist Kuyperianism, the missiological thought of Gustav Warneck, Scottish Pietism and German Romanticism, combined with a naïve hermeneutics that shielded itself from critical scholarship. ${ }^{4}$ The counter-currents were inter alia inspired by Barth's critique of religion, ${ }^{5}$ Bonhoeffer's notion of a confessing church, ${ }^{6}$ historic-critical exegesis, ${ }^{7}$ and the rise of a critically minded, indigenous, black Reformed theology ${ }^{8}$ that presented a credible alternative to what was accepted as "Reformed" at that stage.

We knew that all these intricate and important analyses were crucial to a theological interpretation of the situation. But this was not enough. What was needed, was to use these theological insights to preach differently. Proclamation is the form of Gods' word that reaches ordinary people - black and white. You do not try to win a political or moral argument. You just allow the Word to take its course, believing that that Word will not return empty, but in fact "prosper in the thing for which I sent it" (Is 55:10-11).

What follows is one such example. It is reconstructed from a real sermon, but provided with some theological comments, and adapted to speak beyond one situation only.

\section{'But you, who do you say I am?'9 A Reading of Mark}

It has been argued by both narrative and structural analyses that Mark 8:27-30 (the confession of Peter) is a turning point in the gospel narrative. This passage is the "hinge" of the gospel story that tells of Jesus' ministry up to that point (the road to Caesarea Philippi), and then recounts his journey to the cross (the road to Jerusalem) ${ }^{10}$ Mark sets his aim quite

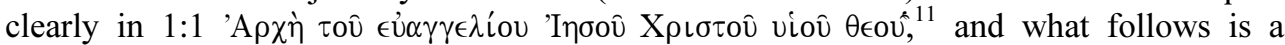
narrative in which the true identity of this Jesus Christ is at stake.

In this regard, the disciple group - those closest to Jesus - are of particular interest. At the point of Jesus' question to them in the narrative, they have been in His presence for quite some time $(1: 17-20 ; 2: 13-14 ; 3: 13-19 ; 6: 7-13)$. They have heard his remarkable teaching - from reinterpreting the Jewish law in general (7:1-23) and more specifically on fasting and the Sabbath $(2: 18-28)$ to explaining his mission and the nature of God's kingdom with parables. ${ }^{12}$ The disciples also witnessed many of Jesus' miracles: these

4 For a short summary of these theological currents, see Naude 2005. For a more elaborate account, see the excellent essays in Kinghorn 1986; and for a classical historical overview, read the anniversary edition of The church struggle in South Africa (De Gruchy and De Gruchy 2004).

$5 \quad$ See Willie Jonker's seminal essay on Barth (Jonker 1988) and the thorough analysis (with extensive literature) of Barth's significance for understanding justice - also in South Africa - by Dirkie Smit (Smit 2004).

6 Nobody did more that John de Gruchy to appropriate Bonhoeffer's insights for the church in South Africa. See specifically his essays in De Gruchy 1984. Under the able leadership of Dirk Smit, then professor of dogmatics at Western Cape, young scholars like Russel Botman and Johann Botha wrote theses on Bonhoeffer, and played an important part in the confessing church movement in South Africa.

7 The academic and popular work by internationally acclaimed scholars like Ferdinand Deist (OT) and Bernard Lategan (NT) played an enormous role to reclaim the Bible for an anti-apartheid reading.

8 Under the leadership of people like Allan Boesak, ABECSA (Alliance of Black Reformed Christians in Southern Africa) that issued their Charter and Declaration in October 1981, played a major role in reclaiming the Reformed tradition in SA to include Black members.

9 In the discussion of the Markan text below, some references will be to the original; most English translations will taken from the RSV, and in some cases I will attempt my own translation.

10 The division of the gospel into a short prologue (1:1-13) followed by two major sections, 1:14-8:30 and 8:31$15: 47$ are based on clear textual markers, and is reinforced by the narrative structure. For the former, with extensive literature, see Moloney 2002:16-22, and for the latter, see Juel (1999), as well as Rhoads (et al) 1999 ( $2^{\text {nd }}$ ed).

11 "The beginning of the gospel of Jesus Christ" with a later addition of "the Son of God".

12 See 4:1-34 for parables of the sower, lamp, seed, and mustard seed. 
include many examples of physical healing, exorcism of devils, as well as the resurrection of Jairus' daughter from death (5:21-43). They witnessed Jesus' power over nature by his stilling of the storm (4:35-41) and walking on the sea (6:45-52), and were intimately involved in the two events narrated as the miraculous multiplication of the bread (6: 30-44; $8: 1-21)$.

A recurring theme in the gospel up to the "confession" pericope, is the vexing question of understanding who Jesus really is. There are numerous clues to this in the text:

The authority of his teaching and power over unclean spirits in Capernaum, lead those present to the question: "What is this? A new teaching! With authority ( $\left.\kappa \alpha \tau^{\prime}{ }^{\prime} \xi_{\xi} \circ{ }^{\prime} \sigma^{\prime} \alpha \nu \cdot\right)$ he commands even the unclean spirits, and they obey him"(1:27) The exorcised devils at that occasion are not permitted to speak, "because they did not know him" (1:34), leaving open Jesus' true identity.

After declaring the lame man's sins forgiven, the question arose: "Who can forgive sins but God alone? (2:7), attesting to some divine power in work in this man from Nazareth.

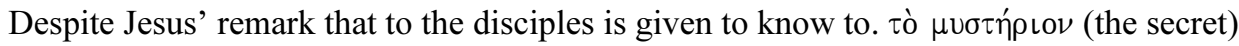
of the kingdom of God (4:11), they are unable to interpret his parables (4:13) and are taught separately from the public at a level that they would understand (4:33-34). That this is a great struggle, emerges after the disciples' question about Jesus' teaching on traditions and inner cleanliness (7:1ff): “Are you also then without understanding?", he asks $(7: 18)$, before explaining again that impurity comes from inside, from the heart, and not through what you eat, i.e. "from outside".

After the stilling of the storm, the disciples are overwhelmed by a great fear, and they

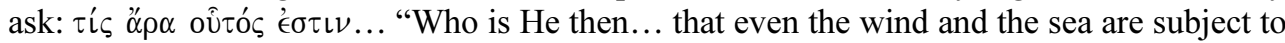
him?" (4:41) Jesus' walking on the sea later in the narrative, is situated in the same "identity question" context. They think they see a ghost, scream loudly, and are clearly upset. He identifies himself (6:50), gets into the boat, and stills the winds. This leaves the disciples "extremely astonished and perplexed" (6:51), and the narrator inserts the clue that real issue is understanding who Jesus is: The disciples are astonished now, it is explained, "because they did not understand about the bread, as their heart was hardened" $(6: 52) .{ }^{13}$

This is reinforced after the second multiplication of the bread: $:^{14}$ They do not understand Jesus' reference to the leaven of the Pharisees and Herod, and interpret his words as a rebuke that they forgot to bring bread into the boat, resulting in a quarrel amongst

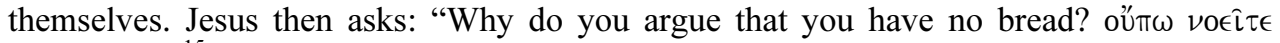
oủó́ $\sigma v v i ́ \in \tau \epsilon^{15}$ Are your hearts hardened? Having eyes do you not see, and having ears do you not hear?" He reminds them of the earlier multiplication of bread, and ends the conversation: "Do you still not understand?" (see 8:17-21)

In his home town, the question of Jesus' true identity is posed with even greater perplexity as they obviously "know" him: "Is he not the carpenter, the son of Mary, and the

13 The passive use of $\kappa \alpha \rho \delta i \alpha \pi \epsilon \pi \omega \rho \omega \mu \epsilon \in \eta \eta$ creates a difficult problem of interpretation as it might suggest that the disciples did not choose to misunderstand Jesus, but were mere passive objects of a divine hardening of the hearts. If one read this passage in the context of Is 6:9-10 (already referred to in 4:12), and link it to Jesus' rebuke of their hardness of heart later $(8: 17)$ and after his resurrection $(16: 14)$, there is no justification to diminish the disciple's agency and responsibility. Just as Jahwe's hardening of Israel's heart in the time of proto- Isaiah was in no way glossing over their own breaking of the covenant. For discussion and literature, see France 2002:273-274.

14 The reason why the bread-miracles are singled out by Mark as the signs of Jesus' true identity - more than the other miracles - might, according to Hooker, be because they are reminiscent of the miraculous manna provision during the exodus (see France 2002:273, footnote 73).

15 "Are you thus without understanding also?" The asunetos has a ring of being dull or foolish to it. 
brother of James...," they ask in 6:3. But where does he get these ideas and what wisdom is given to Him? Whence the power that acts through his hands? (6:2). Mark is clear: They do

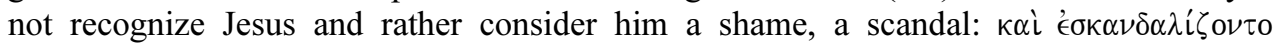
¿́v $\alpha \dot{\tau} \tau \hat{\omega}(6: 3)$.

The other actor in this drama of identifying Jesus is King Herod. He is reported to have heard about the healings in Jesus' ministry (6:14). Whereas some identify Jesus as Elijah, or one or other prophet, Herod himself is convinced that Jesus is a resurrected John the Baptist (6:16). ${ }^{16}$

"Who do the people say I am?" in 8:27 is therefore no question out of the blue. The various audiences - the disciples, the Pharisees and teachers of the law, the crowds in different locations, king Herod, and the impure spirits - all struggled to "pin down" the identity of Jesus.

It is ironic that up to that point, the only replies close to the truth came from the least likely sources: The man with the unclean spirit explicitly confesses: "I know who you are: the Holy One of God" $(1: 24)^{17}$ At two other occasions the demons see Jesus, and it is reported that they call out: "You are the Son of God!" $(3: 11)$, and "Son of the Most High God" (5:7), echoing the very first verse (1:1) which serves as superscript for the whole gospel.

Jesus' self-identification before this question to the disciples is twofold: He calls himself "the Son of Man", able to forgive sins (2:10). and "Kurios": the Lord of the Sabbath (2:28), and the Lord who healed the devil-possessed man from Gerasene (5:19).

The disciples' answer about the peoples' perceptions link Jesus to John the Baptist, Elijah, or one of the prophets (8:28). The crucial question, perhaps expecting a more

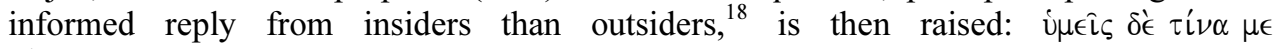
$\lambda^{\prime} \in \gamma \in \tau \epsilon \in \bar{i} \nu \alpha \iota$ (8:29 "But who do you say that I am?")

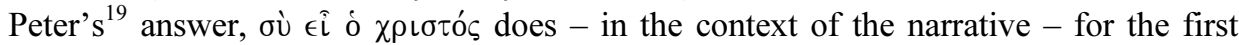
time repeat the announcement at the beginning (1:1). Jesus is identified as the Messiah, the eschatological king who were promised from the Old Testament times (Jer 23:5). Judged purely on its orthodoxy, its theological correctness, the reader is relieved to find that all Jesus' struggles to lead the disciples to a deeper understanding of Himself, bear good fruit. At last they got it right, we think. Is He not, indeed, the Messiah?

At this point the narrative takes on a more dramatic turn: Jesus begins his final journey to Jerusalem, and makes three passion announcements in 8:31-33, 9:30-32, 10:32-34 that are structurally roughly the same: Each of these announcements (varying slightly in content) is followed by a reaction from the disciples (showing yet again their profound

16 This recognition of Jesus by the heathen king is an ironic twist, remarks Edwards (2002:185): He holds Jesus in higher regard than his own people in Nazareth! This may be part of the wider irony - see discussion later that the "lower" the agent (e.g. unclean spirits and Roman officer), the "higher" their knowledge of Jesus. For an extensive study, read J Camery- Hoggat: Irony in Mark's Gospel: Text and subtext. Cambridge: CUP (1992).

17 What happens here is that "the demon displays a supernatural insight as yet denied to human actors in the story. The reader is expected to note it..." (France 2002:10). To call Jesus "holy" is to emphasize the contrast with his "unclean" opponent, and might also refer to Jesus possessing the "Holy Spirit" (1:8) that empowers his messianic ministry.

18 'Jesus' comrades are asked to render a judgment about his remarkable exousia, his divine authority, which they have witnessed and experienced... The disciples must move form the status of passive recipients to active participants" (Edwards 2002:248).

19 Although Peter replies, the context where Jesus addresses the disciples in vv 30-31, suggests that he serves as spokesperson for the disciples. This role of Peter as group representative is repeated in 10:28, 11:21 and 14:37. See France 2002:329. 
misunderstanding of Jesus' person and mission), and a counter-reaction from Jesus (as an attempt to open the disciples' minds).

Jesus does not confirm or deny Peter's confession. He starts to teach them that the Son of $\mathrm{Man}^{20}$ (not the Christ) must suffer and will be rejected by the elders..., that he would be killed, and rise after three days (8:31). Peter's reaction is one of total disbelief: he takes Jesus aside and rebukes Him. Jesus on his part turns around and rebukes Peter in the

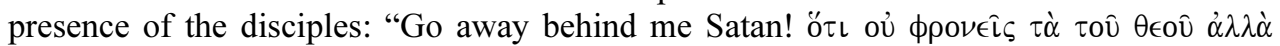
$\tau \grave{\alpha} \tau \hat{\omega} \nu \dot{\alpha} \nu \theta \rho \omega \dot{\omega} \pi \omega \grave{\nu}$. This may be translated as "Because you do not think about the things of God, but those of the people" or more aptly (but less literally) "You are thinking not as God thinks, but as human beings do" (8:33). This is immediately followed by the call to crossbearing: "Whoever wants to follow me must deny himself, take up his cross, and follow Me" (8:34).

In Peter's and the disciples' minds the confession of Christ on the one hand and the announcement of a suffering Son of Man, created a total dissonance, an impossible possibility. The popular conception of the Messiah in Jesus' time was that this Anointed One would destroy God's enemies by the word of his mouth, deliver Jerusalem from the Gentiles, gather the faithful from dispersion, and rule in justice and glory. ${ }^{21}$ And the popular notion of the Son of Man is - according to Jewish Scriptures (Daniel 7) - an apocalyptic figure who would descend from heaven to destroy evil kingdoms and establish the reign of God. ${ }^{22}$ The idea of a suffering, rejected and dying Son of Man -missing the point that he would rise after three days? - was just incomprehensible.

The question arises: Why could the disciples not comprehend Jesus' person and mission? The answer emerges from a close reading of the other two passion announcements:

After announcing his passion, death and resurrection in 9:31, the narrator clearly tells us:

"But they did not understand the saying, and were afraid to ask Him" (9:32) They therefore sensed some danger in the announcement, but could not actually comprehend its meaning. The reasons for the disciples' closed minds are hidden in the following few verses.

The disciples were not open to the meaning of Jesus' passion, because they were talking along the road about who were the greatest amongst themselves (9:34). The same selfinterested power-paradigm that led to a dissonance between "You are the Christ" and "suffering Son of Man", or between following Jesus in his glory and carrying a cross (quite literally), now emerges: In stead of being child-like, the last, and being everybody's servant $(9: 35-37)$, they were arguing who were the biggest, the ruler, the first. ${ }^{23}$

20 This self-identification (used fourteen times only by Jesus) might be ambiguous, but was in the time of Jesus largely free from the political and military connotations of the Messiah. Son of Man is used in three contexts: an apocalyptic context like in Daniel and 1 Enoch $(8: 38 ; 13: 26 ; 14: 62)$, authority to forgive sins and rule over the Sabbath, and predominantly, in the context of suffering (nine times, as in all the passion announcements). For the disciples, the apocalyptic connotation would be most in line with their own expectations.

21 See the short but insightful excursus with further literature on "Christ" in Edwards 2002:249-252.

22 The fact that Jesus calls himself the Son of Man indicates that He will indeed establish the Kingdom of God. This is clear from his opening sermon as reported in Mark 1:14. The problem lies in the means to establish the Kingdom: not via military or political victory as understood in an apocalyptic framework, but through suffering and resurrection. This reinforces the point: the title or description of Jesus per se is not the issue, but the interpretation thereof! For the complex interpretation of the Son of Man in technical literature, and a clear position based on Daniel 7, read Moloney 2002:212-213.

23 What we see here is a juxtaposition "between Jesus' humility and the disciple's desire for distinction and recognition" on the assumption that Messiahship entails privilege, not suffering (Edwards 2002:285) 
This inward focus on retention of power is reinforced when $\mathrm{John}^{24}$ proudly announces that they have seen someone driving out demons in Jesus' Name, but disallowed him to continue. The reason, given twice, is not that the exorcism has been unsuccessful, ${ }^{25}$ but rather: "because he was not following us" (9:38). Jesus opens up their enclosed, sectarian mind-set, ${ }^{26}$ and explains that who is not against us is for us $(9: 40)$, and that even the smallest gift for the sake of Christ (a cup of water), will be rewarded (9:41).

The paradigm of power and glory is revealed the clearest in the third passion announcement: Jesus explains in the greatest detail thus far what suffering and death awaits him in Jerusalem (10: 33-34). James and John - as if no word about suffering was ever mentioned ${ }^{27}$ - clearly expects a crowning, glorious future in which they wish to secretly secure their stake: "Grant us to sit, one at your right hand and one at your left,

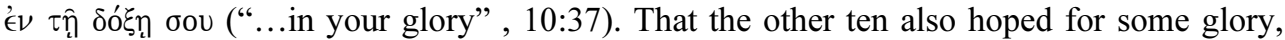
emerges from their upset reaction when they heard about the request from James and John $(10: 41)^{28}$

This is followed by yet another attempt from Jesus to release them from the paradigm of power, dominion, and being "great men" with authority, and in stead understand that in God's kingdom the order is turned exactly upside down. To be the first, you must be everyone's slave (44). ${ }^{29} \mathrm{He}$ ends this passage by reinforcing his passion announcements and

24 John's solo role here should be read as part of the narrator's skilful suggestion that it is precisely the inner circle of the disciples (how close can you be to Jesus!) that misses the point of the suffering Son of Man. See the role of John and James (10:35ff) as discussed below.

25 See a similar event with less satisfactory results in Acts 19:13-16. The "protection" of Jesus' name after his resurrection must have been in the forefront of John's mind; though he expresses this in terms of the exclusive disciple-group and not so much as concern over Jesus' honor!

26 Ideological faith is by its very nature sectarian. Where the nationalistic interest and pious belief intersect, a strong denominational church (in the negative sense) is the inevitable result. As the tension between "us" (who are right and are not properly understood) and "them" (who are out to discredit us) grow, ecumenical isolation increases. But the isolation in turn is not interpreted as Christian exhortation, but exactly as vindication of the truthfulness of the own position. It may take years to change. The ecumenical church in the form of the WCC and SACC (Cottesloe 1961, Message to the People of SA 1968), the Lutheran World Federation (status confessionis 1977) and the World Alliance of Reformed Churches (status confessionis 1982) all played this ambiguous role in the life of the Afrikaans Dutch Reformed Church. The story of the DRC's ecumenical relations between 1960-1990 could be described as a move from willful isolation to reestablishment of ties in full communion. For an overview of critique from the ecumenical church, read De Villiers 1986; for the constructive role of the ecumenical church, read Naude 2003.

27 The heretical nature of self-serving, ideological faith is rarely (if ever) an open denial of orthodoxy. As is clearly the case with John and James here: it is a hermeneutic at work that renders reading the "unacceptable" parts of the gospel impossible, and framing that gospel to fit your own agenda. They just do not hear the explicit "suffering" predictions, but do hear "Son of Man", and that is enough to cling to the apocalyptic notion of a glorious kingdom. To call apartheid a theological heresy was not based on any explicit doctrinal denial by those supporting the system, but the implicit, unsaid "doctrine" that resulted from a racist, pluralist reading of the gospel. See the essays in De Gruchy and Villa-Vicencio 1983.

28 This is the only case in this gospel where James and John are mentioned separately from the twelve. One can easily imagine their intention to sideline Peter, the other member of the inner circle. There are only two positions of glory, but three (if not twelve) contenders.

29 "The preeminent virtue of God's kingdom is not power, not even freedom, but service." Diakonos is the ordinary Greek word for waiting on tables, and doulos was in ancient society the least and the last That a slave can be first is an absurd paradox (Edwards 2002:236). Barth beautifully describes theological work as service: "Since theology is called to serve, it must not rule. It must serve both God in his Word... and the man loved by God and addressed by God's Word. It may rule neither in relation to God nor in relation to men" (Barth 1963:187-188). 
self-identification: "For ${ }^{30}$ the Son of man also came not to be served but to serve, and to give his life as a ransom $(\lambda \dot{u} \tau \rho o \nu)^{31}$ for many" $(10: 45) .{ }^{32}$

In a brilliant ironic twist, the narrator inserts the healing of the blind Bartimaeus here. Jesus asks him exactly the same question as he asked from James and John: "What do you want me to do for you?" (compare 10:51 and 10:36). The disciples asked for glory, the blind man for sight; the disciples were obstructing the way, Bartimaeus "followed him on the way" (10:52).

The entry into Jerusalem that follows here is - in line with the struggle of identity thus far - a confusing event. The readers know Jesus enters to suffer and die, and that his kingdom is from a different order. But He nevertheless enters with the symbolism of a king: riding a colt on which no one has sat (Gen 49:11; Sech 9:9); clothes and branches are spread before him like with a royal inauguration (2 Kings 9:13). The mainly Jewish crowds are swept away in nationalistic fervor: "Hosanna! Blessed is he who comes in the name of the Lord! ${ }^{33}$ Blessed is the kingdom of our father David that is coming! Hosanna in the highest!" $(11: 9-10) .^{34}$

The rest of the gospel emphasizes the failure of the twelve to both understand the significance of the events, and their inability to support their Master in his ordeal. It reinforces the tragic truth set out from the beginning: Those closest to Jesus do not know: Judas is shown to be the traitor (14:18ff); Peter is warned that he would deny Jesus three times (14:27-31), and in the garden the disciples are found sleeping three times, failing Jesus' request to stay and wake (14:32-42). After Judas' betrayal, Jesus is captured by people sent out by the high priests, scribes and elders - echoing the exact actors of his passion announcements. The end of the discipleship journey - apart from Peter who still follows from afar and denies Jesus - is but a terse sentence: "And they all forsook him and fled" (14:50).

The identity question prevails even unto the cross. Jesus is crucified under the ironic script: The king of the Jews. The high priests and law scholars ironically acknowledge his messianic status: "Let the Christ, the King of Israel, come down now from the cross that we can see and believe!" (15:31). When Jesus calls out in Aramaic (Eloi, Eloi,...) some - in line with earlier speculation - mishear him as appealing to $\operatorname{Elijah}^{35}$ for help.

The question: "Who do you say I am?", remains urgent right up to the end. Our hope might be pitched on the women. At least they followed up to the end and are present at the cross. To Mary Magdalene, Mary, the mother of James, and Salome, the news of the

30 The Greek $\gamma \grave{\alpha} \rho$ must be read purposive here and introduces service and giving as the very way of the Son of Man.

31 In the Hellenistic and Roman periods lutron refers to "transactions between human beings and gods in which sins were forgiven and offenses expiated" (Collins as quoted by Edwards 2002:328, footnote 67).

32 There are indications that Mark draws on the Servant of Lord from Is 53 here. This Servant will give his life as guilt offering (Is 53:10) and bear the iniquities of many (53:11), in the same way that Jesus describes the Son of Man here. For a discussion, and with literature presenting alternatives, see Moloney 2002:213-214.

33 A direct quotation of Psalm 118:25-26 as a referral to pilgrims' entering Jerusalem.

34 For the sake of my specific reading, i.e. to uncover the traits of ideological faith, I am less open to Edwards' suggestion that the crowds did not harbor messianic expectations from Jesus, but merely welcomed him as a pilgrim (2002:336-7). In line with the narrator's emphasis on "misunderstanding", the shift from "the kingdom of God" (Jesus) to "the kingdom of our father David" (crowds) is highly significant. This identification of political interests with divine interest is the deepest core of an ideological faith. That the Markan account of Jesus' entry is significantly "down-scaled" when compared with Matthew and Luke, is true, but this does not detract from the misreading of Jesus' purpose and identity by those present.

35 It was believed that Elijah had been taken to heaven without dying (2 Kings $2: 11$ ), and that he could return to help the righteous in times of crises. 
resurrection is later told. They are requested by the young man in white clothes to go and tell others to meet Jesus in Galilee. The original text of the gospel, however, ends in disappointment: "And they said nothing to any one, for they were afraid" (16:8).

We saw earlier that - contrary to expectation - the unclean spirits knew Jesus. When everyone else was struggling to understand, they confessed: "You are the Son of God" (3:11). At the end, it is left to the Roman soldier, an officer over hundred men, who had no

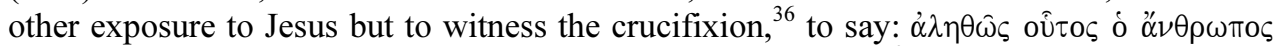
viò $\theta \in$ Єô ทे $\nu$ ("Truly, this man was the Son of God", 15:39). ${ }^{37}$ What no one could fully comprehend during Jesus' life and ministry, becomes possible through his death.

This exposition may aid us in understanding two interesting remarks in the first encounter between Jesus and Peter after the latter made his confession. The one is the command to keep quiet, and the other is the reference that Peter is a Satan.

Jesus' strong insistence that they should tell no one that he is the Christ, has become known in scholarship as the messianic secret. ${ }^{38}$ It is a complex theme recurring in contradictory modes in the narrative: Sometimes someone is urged to go and tell (e.g. the man from Gadarene in 5:19); but mostly people who are healed, are asked not to tell (e.g. $1: 44 ; 5: 43 ; 7: 35$ and $8: 26)$.

If one reads the identity question of the Markan narrative as playing itself out in the tension between two radically opposing paradigms (reminiscent of Luther's theologies of glory and the cross), the insistence not to tell anyone about the Christ in 8:30 specifically, is explained: Jesus is well aware of the nationalistic and self-indulgent misinterpretation of his mission. He understands that his disciples are following him because of their expectation for dominion and glory. This type of Christ is dangerous: "Do not tell others about Him".

The problem lies not in the words of the confession. Jesus is indeed the Christ. The problem - as we saw earlier - lies in the interpretation of this Christ, and the consequences it has for the practical choices made by the disciples. They were dogmatically correct, but were still standing in God's way; closing out others in a sectarian mind-set; struggling for being the most important; involved in a secret politicking for positions of glory; and clearly over-estimated their own religious loyalties to Christ.

Seemingly orthodox statements are shattered by heterodox attitudes and actions. Theology is constitutively verified or falsified through ethics.

36 In the Matthew version (27:54), the centurion's confession is a reaction to the signs accompanying Jesus' death, here the confession is a direct response to the death of Jesus itself. See the good argument by Davis (1989) that 15:39 should not merely be seen as the climax of the gospel, but as the governing key to interpret the gospel as such. What we find is not merely a narrative climax, "but the Christological climax as well" (Davis 1989:14).

37 There are no grammatical grounds for the assertion (inter alia by Johnson 1987:14) that, because of the absence of a definitive article before Son of God, the centurion only hade a general confession about a son of god, i.e. a special person. As Edwards rightly point out, a definitive predicate nominative in Koine Greek omits the article when it precedes the verb (2002:480). What we have here - according to the narrative - is a full confession in line with the intention of the gospel as set out in 1:1.

38 The modern scholarship on Mark has been set in motion by the groundbreaking work, Das Messiasgeheimnis in den Evangelien, by Wilhelm Wrede in 1901. His enduring legacy is that Mark is a theological work (not a mere biographical account), and that Christology forms the centre of that theology. For a discussion of the reaction to Wrede and major viewpoints up to the mid 1960's, read David Aune's instructive article, The problem of the messianic secret (1969), specifically pp 1-8 with discussions on major scholars from Schweitzer to Bultmann. My fairly straightforward explanation of the messianic secret stems from the specific hermeneutical angle from which I chose to read Mark, and is perhaps a good illustration of Bultmann's work on presuppositions! 
By rebuking Jesus for his passion announcement, Peter is acting naturally. He tries to defend his prevailing paradigm of Christ. His mind is thinking like the minds of people, and he cannot think the way God thinks. He wants to avoid the cross; he wants to save himself. That is equal to being Satan (8:33). By opposing God's will for his Messiah, Peter and the disciples "are acting as spokesmen of God's ultimate enemy" in his role as taking away the word of God (see Mark 4:15, France 2002:338). What we see here are "incompatible ideologies" at work, where a human perspective is incapable of grasping divine purpose (France 2002:339).

History teaches us: Where this paradigm of power becomes institutionalized and moves beyond individual notions of Christ for the sake of myself and my in-group, we find the deadly combination of nationalistic politics and the Christian religion. The most dramatic $20^{\text {th }}$ century examples are National-Socialism in Germany and apartheid theology in South Africa. Both linked a people (Volk), a specific land, and God, in an ideological triangle in which the church and ordinary people confessed Christ in an orthodox manner, whilst dehumanizing others in their narrow pursuit of privilege, power and racial self-glorification. You could kill in the Name of the One you confess. By God's grace, the alternative truth, the rejection of ideological faith, was also spoken in both countries as represented by Barmen (1934) and Belhar (1982/86). An emerging $21^{\text {st }}$ century example is the preemptive wars initiated by the USA, exhibiting in some respects the same ideological structure of a Christian God identified with Western political values, and the protection of American interests and security.

Over against this Satanic temptation to seek power, influence and glory, stands the utter foolish paradigm of the cross.

\section{Is there Hope for Liberation from an Ideological Faith?}

The urgent question that now arises is whether there is hope. Is there a possibility that Peter and the disciples can indeed come to an understanding of who Jesus is and shape their lives accordingly? In the context of prevailing Christian ideologies: Is there an expectation that those caught up in a paradigm of power, legitimized by theology and supported by political and military means, can indeed turn around?

The story of Peter (as representative of the disciples, and for that matter all followers of Christ) gives us the clue. Conversion to a radically new insight is possible through divine intervention.

First, Peter's religious self-confidence had to be shattered by a practical realization that he - despite his good Messianic intentions - has been betraying Christ. A simple maid in the house of the high priest and a cock that crows twice are the instruments ${ }^{39}$ of shaking the ideological foundations of Peter's faith. (It is yet again ironic that Peter denies knowledge of Jesus whilst confessing and protesting all along that he does!) In a fleeting moment he realizes who he really is: a follower and defender, but at the same time a traitor of Christ. The narrator tells of the effect: "And he broke down and wept" (14:72). ${ }^{40}$

39 Sometimes - God forbids - the "instrument" to destabilize an ideological self, is war and destruction to the point of no return. In other cases, one only realizes those moments when you look back. In the South African case, two seemingly simple events that contributed to insight in the ideological faith of Afrikaner Christians were the rejection of mixed marriages on Scriptural grounds by leading ethicists like De Villiers and Kinghorn in the late 1970's, and the declaration of apartheid theology as status confessionis accompanied by the draft Confession of Belhar by the "coloured" Mission Church in 1982. It still took some time, but these two viewpoints eroded the moral legitimacy of the system in the minds of ordinary white Christians.

40 This happens at an individual level - sometimes like here with Peter - in an instant. Bonhoeffer writes in Sanctorum Communio (published 1930) that ethical responsibility may be assigned not only to individuals, 
The readers, and the later addition to the ending of the Markan gospel (16:9-20), know the second part of the radical conversion: The destruction of the previous religious edifice, the revelation of the true self and the breaking down of all spiritual self-confidence, make room for a fresh meeting - this time with the resurrected Christ. ${ }^{41}$ Again Jesus reprimands them for their hardness of heart and disbelief, ${ }^{42}$ but then - in a gesture of radical grace and acceptance - He empowers them, the very ones who did not understand and at first did not believe, to go into the world, and "preach the gospel to the whole creation" $(16: 15)$. Because they then knew the whole gospel. They understood for the first time that the suffering Son of Man is indeed the resurrected Christ.

In the words of Michael Welker, "Reformed theology must engage in a variety of ways in the effort to renew a theology of the word of God, and above all, it must make clear that the church of Christ lives in the presence of the risen Christ" (1999:141, my emphasis). We have the promise that - no matter our past - the risen Christ will work with us and confirm our message by the signs that attend it (Mark 16:19).

Whilst we follow Christ in his command, let us be aware of the ever present danger of new ideological faiths: The rise of Islamic and Christian fundamentalism in the MiddleEast, Africa and the USA; the link between neo-liberal capitalism and a prosperity gospel; the rapid growth of spiritualities that utilize the mass media to turn the Christian gospel into anthropocentric and pleasing entertainment.

"Who is Jesus Christ for us today?" (Bonhoeffer), might be the most important question to answer.

\section{BIBLIOGRAPHY}

Aune, David E 1969. The problem of the Messianic secret. Novum Testamentum 11, 1-31. Barth, Karl 1963. Evangelical theology: An introduction. New York: Holt, Rinehart and Winston.

Bonhoeffer, Dietrich 1998. Santorum Communio. A theological study of the sociology of the church. Minneapolis: Fortress.

but to the whole people of God. There is something like "ethical collective persons" (Bonhoeffer 1998: 118) and collective guilt that may gradually dawn. Chances are slim that self-realization reaches everyone at the some time: "Breaking down and weeping", expression of guilt and sorrow, are mostly expressed not by all, but vicariously by some on behalf of all - even if they are not each and every one convinced at the time, and even whilst they fiercely resist and refuse to accept the radically other picture of the collective self. The confession of Willie Jonker on behalf of Afrikaners and the DRC at the ecumenical Rustenburg conference (read the text in Jonker 1991), as well as the DRC's own confession of guilt in 1990, stand out as crucial markers on the road to proper insight into "Christian" policies of apartheid. The role of the Truth and Reconcilition Commission - accompanied by many tears and personal confessions - has been described by some as a national catharsis, a deep look inside our own hearts of darkness (Pauw); a view into the skull of our country (Krog).

${ }^{41}$ "The good news does not say: Jesus is simply here again! The pre-Easter Jesus of Nazareth is here again! Instead, the good news, the gospel, says: here is the risen and exalted Christ, who is present in a wholly new way." For that reason the gospel is also called the "gospel of the resurrection" (Welker 1999a:148, emphasis original).

42 This is quite instructive: Jesus does not gloss over, but in fact reminds them of their past in the very act of commissioning them! Much has been written about historical guilt. Theologically speaking, the only guilt that is both painful and empowering to remember, is guilt covered by the grace of God according to his promise in 1 John 1:7-9, and repeated every Sunday after the reading of the law. The re-commissioning of the church in SA - those who designed and supported apartheid, together with those who fought against the system - can only happen on the basis of remembered grace. In a country ravaged by the Aids-pandemic, violent gender crime, and a growing poverty-gap, there is so much that needs to be done theologically and in practice. 
Childs, Brevard S 1993. Biblical theology of the Old and New Testaments. Theological reflection on the Christian bible. Minneapolis: Fortress.

De Gruchy, John W 1984. Bonhoeffer and South Africa: Theology in dialogue. Grand Rapids: Eerdmans.

De Gruchy John W (with De Gruchy Steve) 2004. The church struggle in South Africa. $25^{\text {th }}$ Anniversary edition. London: SCM.

De Gruchy John and Villa-Vicencio Charles (eds.) 1983. Apartheid is a heresy. Cape Town: David Philip.

Davis, Philip G 1989. Mark’s Christological paradox. JSNT 35:3-18.

De Villiers, Etienne 1986. Kritiek uit die ekumene. In Johann Kinghorn (ed), 144-164.

Edwards, James R 2002. The gospel according to Mark. Grand Rapids: Eerdmans.

France, RT 2002. The gospel of Mark. Grand Rapids: Eerdmans.

Giliomee, Hermann 2003. 'The weakness of some": The Dutch Reformed Church and white supremacy. Scriptura 83: 212-244.

Johnson, Earl S 1987. Is Mark 15:39 the key to Mark's Christology? JSNT 31, 3-22.

Jonker, Willie. 1988. Some remarks on the interpretation of Karl Barth. NGTT 29:29-40.

Jonker, Willie 1991. Understanding the church situation and obstacles to Christina witness in South Africa. In Louw Alberts \& Frank Chikane (eds.) The road to Rustenburg. The church looking forward to a new South Africa. Cape Town: Struik, 87-98.

Juel, Donald H 1999. The gospel of Mark. Nashville: Abingdon.

Kinghorn, Johann (red.) 1986. Die NG Kerk en apartheid. Johannesburg: Macmillan.

Moloney, Francis J 2002. The gospel of Mark. A commentary. Grand Rapids: Eerdmans.

Naude, Piet 2003. The theological coherence between the Belhar confession and some antecedent church witnesses in the period 1948-1982. Verbum et ecclesia 42 (1): 156-179.

Naude, Piet 2005. From pluralism to ideology: The roots of apartheid theology in Abraham Kuyper, Gustav Warneck and theological Pietism. Scriptura 88: 161-173.

Oberdorfer, Bernd 1998. Biblisch-realistische Theologie: Methodologische Ueberlegungen zu einem dogmatischen Programm. In S Brandt und B Oberdorfer (Hrsg.) Resonanzen: Theologische Beiträge. Wuppertal: Foedus, 63-83.

Rhoads, D, Dewey, J \& Michie, D 1999. Mark as story: An introduction to the narrative of the gospel. $2^{\text {nd }}$ ed. Philadelphia: Fortress.

Smit, Dirk J 2004. “...The doing of the little righteousness": On justice in Barth's view of the Christian life. In Michael Welker \& Cynthia A Jarvis (eds.): Loving God with our minds. The pastor as theologian. Essays in honor of Wallace M Alston. Grand Rapid: Eerdmans, 120-145.

Welker, Michael 1999a. Travail and mission: Theology reformed according to God's Word at the beginning of the third millennium. In David Willis and Michael Welker (eds.): Toward the future of reformed theology. Tasks, topics, traditions, Grand Rapids: Eerdmans, 136-152.

Wenham, David \& Walton, Steve 2001. Exploring the New Testament (volume 1: Introducing the Gospels and Acts). London: SPCK. 